\title{
Hydrogen Production by Steam Reforming of Ethanol over Nickel Catalysts Supported on Sol Gel Made Alumina: Influence of Calcination Temperature on Supports
}

\author{
Zahira Yaakob ${ }^{1, *}$, Ahmed Bshish ${ }^{1}{ }^{1 *}$, Ali Ebshish ${ }^{1}$, Siti Masrinda Tasirin ${ }^{1}$ and \\ Fatah H. Alhasan ${ }^{2}$
}

1 Department of Chemical and Process Engineering, Faculty of Engineering, Universiti Kebangsaan Malaysia (UKM), Bangi, Selangor 43600, Malaysia; E-Mails: aliebshish@gmail.com (A.E.); masrinda@eng.ukm.my (S.M.T.)

2 Catalysis Science and Technology Research Centre, Faculty of Science, Universiti Putra Malaysia, UPM Serdang, Selangor 43400, Malaysia; E-Mail: abuomohd999@yahoo.com

* Authors to whom correspondence should be addressed; E-Mails: zahira65@yahoo.com (Z.Y.); ahmedbshish@gmail.com (A.B.); Tel.: +603-8921-6420 (Z.Y.); +601-2905-9220 (A.B.); Fax: +603-8921-6148 (Z.Y./A.B.).

Received: 31 January 2013; in revised form: 7 April 2013 / Accepted: 28 April 2013 /

Published: 30 May 2013

\begin{abstract}
Selecting a proper support in the catalyst system plays an important role in hydrogen production via ethanol steam reforming. In this study, sol gel made alumina supports prepared for nickel (Ni) catalysts were calcined at different temperatures. A series of $\left(\mathrm{Ni} / \mathrm{Al}_{\mathrm{S} \text {.G. }}\right)$ catalysts were synthesized by an impregnation procedure. The influence of varying the calcination temperature of the sol gel made supports on catalyst activity was tested in ethanol reforming reaction. The characteristics of the sol gel alumina supports and Ni catalysts were affected by the calcination temperature of the supports. The structure of the sol gel made alumina supports was transformed in the order of $\gamma \rightarrow(\gamma+\theta) \rightarrow \theta$-alumina as the calcination temperature of the supports increased from $600{ }^{\circ} \mathrm{C}$ to $1000{ }^{\circ} \mathrm{C}$. Both hydrogen yield and ethanol conversion presented a volcano-shaped behavior with maximum values of $4.3 \mathrm{~mol} / \mathrm{mol}$ ethanol fed and $99.5 \%$, respectively. The optimum values were exhibited over $\mathrm{Ni} / \mathrm{Al}_{\mathrm{S} . \mathrm{G} 800}$ ( $\mathrm{Ni}$ catalyst supported on sol gel made alumina calcined at $800{ }^{\circ} \mathrm{C}$ ). The high performance of the $\mathrm{Ni} / \mathrm{Al}_{\mathrm{S} . \mathrm{G} 800}$ catalyst may be attributed to the strong interaction of Ni species and sol gel made alumina which lead to high nickel dispersion and small particle size.
\end{abstract}


Keywords: ethanol reforming; hydrogen production; sol gel alumina; nickel catalyst

\section{Introduction}

Hydrogen is a potential source of clean energy mainly as fuel in fuel-cell systems, which are described as continuously operating batteries. It is also one of the cleanest and greenest sources of electrical energy [1,2]. The production of hydrogen by ethanol steam reforming was achieved using different catalytic systems. Our group [3] performed an extensive review on various catalytic systems employed in hydrogen production through ethanol reforming. Nickel (Ni) on different supports has been broadly investigated in ethanol steam reforming reaction because of its inexpensive nature and its wide use in the hydrogenation and steam reforming of hydrocarbons [4-9]. The activity of a catalytic system depends on several factors, such as active metal, nature of support, precursor used, method adopted for catalyst preparation, presence of promoters, and reaction conditions, including water-to-ethanol molar ratio, temperature, and space velocity. The nature of support has a significant effect on the characteristics and activity of catalysts. Conventional impregnation of commercial $\mathrm{Al}_{2} \mathrm{O}_{3}$ support is widely used in the synthesis of Ni-based catalysts because of its fast and simple operation [10-16]. Ni-based catalysts prepared using sol gel made $\gamma$-alumina support have higher hydrogen selectivity and ethanol conversion than those prepared using commercial $\gamma$-alumina support [17]. However, there are several reports about the use of nickel supported on sol gel made alumina for hydrogen production via steam reforming of natural gas [17-19]. A survey of literature showed that no work has been done so far on the production of hydrogen using nickel supported on sol gel made alumina catalyst via steam reforming of ethanol. The physical and chemical properties of alumina support are influenced by the treatment temperature of the alumina. Accordingly, the activity of $\mathrm{Ni}$ catalysts supported on sol gel made alumina (denoted as $\mathrm{Al}_{\mathrm{S} \text {.G. }}$ ) in ethanol steam reforming is influenced by the calcination temperature of the support. Thus, this study aims to prepare $\mathrm{Al}_{\text {S.G. }}$. supports calcined at different temperatures. $\mathrm{Ni} / \mathrm{sol}$ gel made alumina (denoted as $\mathrm{Ni} / \mathrm{Al}_{\mathrm{S} . \mathrm{G} \text {. }}$ ) catalysts were synthesized by an impregnation procedure and then tested for hydrogen production via ethanol steam reforming. The influence of the calcination temperature of $\mathrm{Al}_{\text {S.G. }}$ on the activity of the Ni/Al $\mathrm{A}_{\text {S.G. }}$ catalysts in hydrogen production via ethanol reforming reaction, was studied.

\section{Experimental Section}

\subsection{Catalyst Preparation}

$\mathrm{Al}_{\text {S.G. }}$ supports were prepared according to a previously described method [17]. Approximately $96 \mathrm{~g}$ of the precursor aluminum sec-butoxide (Sigma-Aldrich) was dissolved in $828 \mathrm{~mL}$ of ethyl alcohol under constant stirring at $80{ }^{\circ} \mathrm{C}$ (solution 1) to prepare $20 \mathrm{~g}$ of $\mathrm{Al}_{2} \mathrm{O}_{3}$ xerogel. $\mathrm{HNO}_{3}(1.37 \mathrm{~mL})$ and distilled water $(4.12 \mathrm{~mL})$ diluted with $549 \mathrm{~mL}$ ethyl alcohol (solution 2) were mixed with solution 1 . This mixture was fixed at $80{ }^{\circ} \mathrm{C}$ to form the sol. After cooling the sol, a transparent gel was obtained by slowly pouring $8.23 \mathrm{~mL}$ distilled water and $68.66 \mathrm{~mL}$ ethyl alcohol into the sol. The alumina gel was covered and kept for a day before it was dried overnight. The formed solid was calcined at 
different temperatures to obtain the alumina sol gel. This support was denoted as $\mathrm{Al}_{\text {S.G.T }}$, where $\mathrm{T}$ is the support calcination temperature (varied from $600{ }^{\circ} \mathrm{C}$ to $1000{ }^{\circ} \mathrm{C}$ at an interval of $100{ }^{\circ} \mathrm{C}$ ).

$\mathrm{Ni}$ supported on sol gel alumina catalysts was synthesized by an impregnating amount of $\mathrm{Ni}\left(\mathrm{NO}_{3}\right)_{2} \cdot 6 \mathrm{H}_{2} \mathrm{O}$ (Sigma-Aldrich) on the $\mathrm{Al}_{\text {S.G. }}$ supports. The synthesized catalysts were denoted as

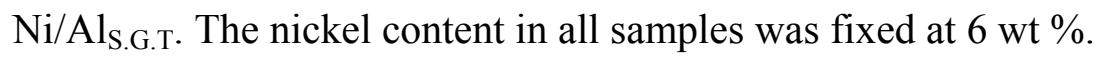

\subsection{Catalyst Characterization}

The Brunauer-Emmett-Teller (BET) surface area, pore volume, and pore size distribution of the supports were measured by $\mathrm{N}_{2}$ adsorption at $77 \mathrm{~K}$ using a Micromeritics adsorption equipment (Model ASAP 2010, Micromeritics Instruments Inc., Norcross, USA) using $\mathrm{N}_{2}$ gas (99.99\% purity).

The X-ray diffraction (XRD) patterns of the samples were recorded at $2 \theta$ ranging from $10^{\circ}$ and $80^{\circ}$ on a Bruker AXS D8 Advance diffractometer employing a scanning rate of $0.02^{\circ} \mathrm{s}^{-1}$ with $\mathrm{Cu} \mathrm{K \alpha}$ radiation $(\lambda=1.5418)$. The working current and voltage of the $\mathrm{X}$-ray tube were $30 \mathrm{~mA}$ and $40 \mathrm{kV}$.

Temperature-programmed reduction (TPR) measurements were performed for all catalysts using a Micromeritics instrument (Model Autochem II 2920, Quantachrome Corporation, FL, USA) connected to a thermal conductivity detector (TCD). The temperature was elevated from $25{ }^{\circ} \mathrm{C}$ to $900{ }^{\circ} \mathrm{C}$ at a rate of $10{ }^{\circ} \mathrm{C} \mathrm{min}{ }^{-1}$. For TPR analysis, a mixed stream of $5 \% \mathrm{H}_{2}-\mathrm{N}_{2}$ mixture as carrier gas was passed on $0.03 \mathrm{~g}$ of catalyst sample at a flow rate of $20 \mathrm{~cm}^{3} \mathrm{~min}^{-1}$. Hydrogen chemisorption measurements were performed to determine the dispersion, particle size, and surface area of nickel. Initially, the system was purged with pure argon $\left(30 \mathrm{~mL} \mathrm{~min}{ }^{-1}\right)$ from room temperature to $900{ }^{\circ} \mathrm{C}$ for $1 \mathrm{~h}$. Prior to the chemisorption measurements, the catalyst was treated with a mixed stream of carrier nitrogen $\left(20 \mathrm{~mL} \mathrm{~min}{ }^{-1}\right)$ and $\operatorname{argon}\left(20 \mathrm{~mL} \mathrm{~min}^{-1}\right)$ by elevating the temperature from $25^{\circ} \mathrm{C}$ up to $900{ }^{\circ} \mathrm{C}$ for $3 \mathrm{~h}$ to remove any impurities. After cooling down, the catalysts were reduced in situ with hydrogen at $400{ }^{\circ} \mathrm{C}$ for $1 \mathrm{~h}$. The samples were then cooled to room temperature under argon flow $\left(30 \mathrm{~mL} \mathrm{~min}^{-1}\right)$. The quantity of hydrogen uptake was measured by passing diluted hydrogen ( $5.1 \%$ hydrogen in argon) through the catalyst. The dispersion, surface area, and mean particle size of nickel were evaluated according to Equations (1-3), respectively.

$$
\begin{gathered}
D_{m}=\frac{V_{\text {chem. } .} \times S F \times M W}{c / 100} \times 100 \\
S . A_{\cdot m}=V_{\text {chem. }} \times 6.02 \times 10^{23} \times S F \times \sigma_{m} \times 10^{-18} \\
d=\frac{6 \times c}{\left(S . A_{\cdot m}\right) \times \rho} \times 100
\end{gathered}
$$

where,

$D_{m}=$ Metal dispersion

$V_{\text {chem. }}=$ Chemisorption volume $\left(\mathrm{mol} \mathrm{g}^{-1}\right)$

$S F=$ Stoichiometry factor $=1$

$M W=$ Supported metal atomic weight

$c=$ Supported metal weight, wt $\%$

$S . A \cdot_{m}=$ Metal surface area (per g catalyst)

$\sigma_{m}=$ Supported metal cross section area $=0.0649 \mathrm{~nm}$ atom $^{-1}$ 
$d=$ Mean particle diameter $(\mathrm{nm})$

$\rho=$ Supported metal density

The amount of carbon deposited on the used catalyst surface was measured for each sample by performing CHNS elemental analysis with a Leco CHNS-932 Elemental Analyzer, and $2.073 \mathrm{mg}$ of the used sample was treated at high temperature in air.

\subsection{Catalyst Performance Test}

Hydrogen production by ethanol steam reforming was used as a test reaction for all prepared catalysts. Reforming reaction was performed in a Pyrex glass tube reactor (internal diameter: $8 \mathrm{~mm}$, length: $50 \mathrm{~cm}$ ) at $400{ }^{\circ} \mathrm{C}$ and atmospheric pressure. Before the reaction takes place, the catalyst was heated up to $150{ }^{\circ} \mathrm{C}$ for $1 \mathrm{~h}$ to remove impurities and then reduced at reaction temperature in situ under flowing $\mathrm{H}_{2}$ for another $1 \mathrm{~h}$. A mixture of liquid water and ethanol with a molar ratio 6:1 was

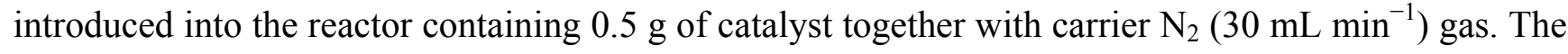
reactant mixture was fed to the reactor by using a syringe pump (model NE-300) fixed at the required flow rate $\left(0.1 \mathrm{~mL} \mathrm{~min}^{-1}\right)$. The temperature inside the reactor was controlled and measured by using a thermocouple located in the catalyst bed. The catalytic data were recorded after $8 \mathrm{~h}$ reaction. The output gas stream was analyzed through gas chromatography (SRI 8610C Gas Chromatograph, USA) using a molecular sieve, a silica gel column, and a TCD with helium as the carrier gas. Each sample was analyzed at least twice, and the average was estimated. Condensed liquid was collected and analyzed by GC (SUPELCO) equipped with an Equity-1 capillary column $(30 \mathrm{~m} \times 0.32 \mathrm{~mm} \times 0.1 \mu \mathrm{m})$ and a flame ionization detector.

The criteria used to evaluate catalyst performance included ethanol conversion and $\mathrm{H}_{2}$ yield. Equations (4) and (5) were used to calculate ethanol conversion and hydrogen yield, respectively.

$$
\begin{gathered}
\text { EtOH Conversion }=\frac{F_{\text {ETOH }_{\text {in }}}-F_{\text {ETOH }_{\text {out }}}}{F_{\text {ETOH }}} \times 100 \\
H_{2} \text { Yield }=\frac{F_{H_{2, \text { out }}}}{F_{E T O H_{\text {in }}}}
\end{gathered}
$$

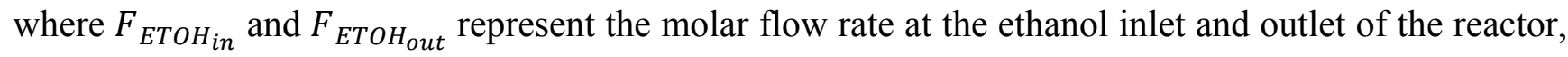
respectively, and $F_{H_{2} \text { out }}$ represents the flow rate at the hydrogen outlet of the reactor.

\section{Results and Discussion}

\subsection{Support Physical Properties}

The physical properties of $\mathrm{Al}_{\text {S.G. }}$ calcined at different temperatures ranging from $600{ }^{\circ} \mathrm{C}$ to $1000{ }^{\circ} \mathrm{C}$ were tested by $\mathrm{N}_{2}$ adsorption-desorption isotherm determination (Figure 1). The samples exhibited type-IV (based on the International Union of Pure and Applied Chemistry) curves, indicating the presence of a mesoporous material. Interestingly, the calcination temperature of the supports showed an influence on hysteresis loops. That is, the hysteresis loops shifted to lower relative pressure with decreasing calcination temperature. This result indicates that the pore size of $\mathrm{Al}_{\text {S.G. }}$ increased with 
increasing calcination temperature. This finding may be attributed to the development of pore texture with a relatively broad pore size distribution.

Figure 1. Nitrogen adsorption-desorption isotherms for sol gel alumina supports at different calcinations temperature.

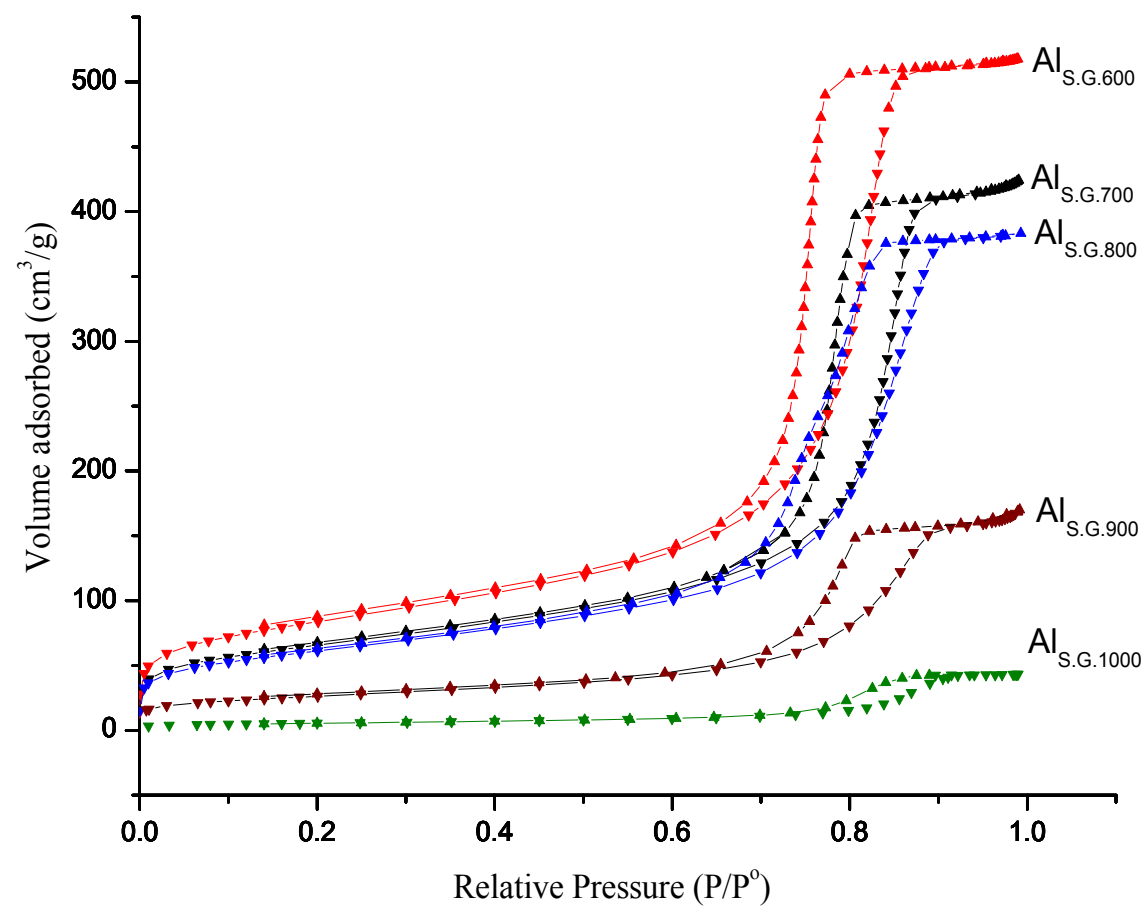

Table 1 summarizes the physical properties of the $\mathrm{Al}_{\text {S.G. }}$ supports. The surface area of all prepared alumina supports decreased from $292 \mathrm{~m}^{2} \mathrm{~g}^{-1}$ at $600{ }^{\circ} \mathrm{C}$ to $19 \mathrm{~m}^{2} \mathrm{~g}^{-1}$ at $1000{ }^{\circ} \mathrm{C}$. Similarly, pore volume decreased as the calcination temperature of the supports increased. Noticeably, the pore volume and surface area of the supports considerably declined at $1000{ }^{\circ} \mathrm{C}$. By contrast, the pore diameter of $\mathrm{Al}_{\text {S.G. }}$. increased with increasing calcination temperature. This result suggests that the physical properties of the $\mathrm{Al}_{\text {S.G. }}$ supports were significantly influenced by calcination temperature which is agree with the data of previous studies [20-22].

Table 1. Physical properties of sol gel made alumina supports at different calcination temperatures.

\begin{tabular}{cccc}
\hline Catalyst name & BET $\left(\mathbf{m}^{\mathbf{2}} / \mathbf{g}\right)^{\mathbf{a}}$ & Pore volume $\left(\mathbf{c m}^{\mathbf{3}} / \mathbf{g}\right)^{\mathbf{b}}$ & Pore diameter(nm) \\
\hline $\mathrm{Al}_{\text {S.G. } 600}$ & 292 & 0.81 & 7.91 \\
$\mathrm{Al}_{\text {S.G. } 700}$ & 230 & 0.67 & 8.46 \\
$\mathrm{Al}_{\text {S.G. } 800}$ & 214 & 0.60 & 9.06 \\
$\mathrm{Al}_{\text {S.G. } 900}$ & 92 & 0.27 & 9.10 \\
$\mathrm{Al}_{\text {S.G. } 1000}$ & 19 & 0.07 & 10.18 \\
\hline
\end{tabular}

${ }^{\mathrm{a}}$ Calculated by the BET equation; ${ }^{\mathrm{b}} \mathrm{BJH}$ desorption pore volume; ${ }^{\mathrm{c}} \mathrm{BJH}$ desorption pore diameter.

\subsection{Effect of Calcination Temperature on the Structure of the Supports and Supported Ni Catalysts}

The effect of calcination temperature on the phase transformation and phases of the $\mathrm{Al}_{\mathrm{S} \text {.G. }}$ supports was tested by XRD measurements (Figure 2a). The supports calcined at temperatures ranging from 
$600{ }^{\circ} \mathrm{C}$ to $800{ }^{\circ} \mathrm{C}$ showed similar diffraction peaks belonging to $\gamma$-alumina. However, the alumina supports calcined at $900{ }^{\circ} \mathrm{C}$ exhibited two mixed phases of alumina $(\gamma$ and $\theta)$ because the alumina support transformed from $\gamma$ - to $\theta$-alumina at this calcination temperature. As expected, the support calcined at $1000{ }^{\circ} \mathrm{C}$ showed characteristic peaks corresponding to $\theta$-alumina. However, the $\alpha$-alumina phase was not detected at this temperature. The transformation of alumina phases occurs because of dehydroxylation and sintering reactions [20,21], wherein the rate of these reactions varies by changing the calcination temperature of the support. Generally, the phase of $\gamma$-alumina can be detected at temperatures lower than or equal to $800{ }^{\circ} \mathrm{C}$, whereas that of $\theta$-alumina appears at temperatures above $800{ }^{\circ} \mathrm{C}$ and becomes more intense at $1000{ }^{\circ} \mathrm{C}$.

Figure 2. XRD patterns of (a) sol gel made alumina supports and (b) nickel catalysts supported on sol gel made alumina supports.
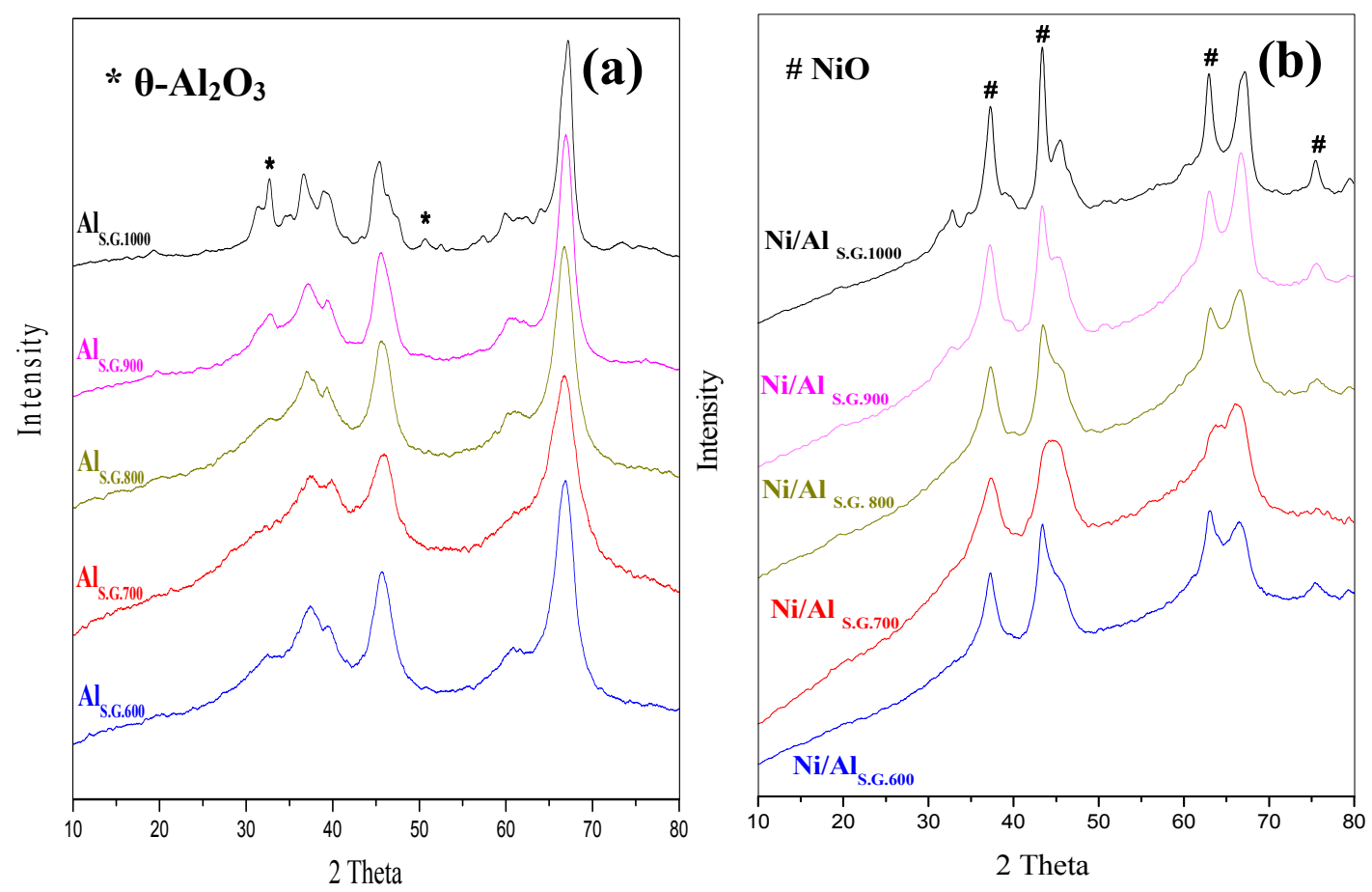

The XRD diffraction peaks of the $\mathrm{Ni} / \mathrm{Al}_{\mathrm{S} \text {.G. }}$ catalysts are shown in Figure $2 \mathrm{~b}$. All Ni/Al $\mathrm{l}_{\text {S.G. }}$ catalysts exhibited peaks belonging to nickel oxide $(\mathrm{NiO})$. The diffraction peaks of $\mathrm{NiO}$ shifted to a higher angle as the calcination temperature of the support increased, as evidently observed in the $\mathrm{Ni} / \mathrm{Al}_{\mathrm{S} . \mathrm{G} 1000}$ catalyst. The strong and narrow $\mathrm{NiO}$ peaks exhibited over the $\mathrm{Ni} / \mathrm{Al}_{\mathrm{S} . \mathrm{G} 1000}$ catalyst can be ascribed to the weak interaction between $\mathrm{Ni}$ species and the $\mathrm{Al}_{\text {S.G. }}$ supports. By contrast, the high surface area of the supports over the catalysts $\left(\mathrm{Ni} / \mathrm{Al}_{\mathrm{S} . \mathrm{G} 600}, \mathrm{Ni} / \mathrm{Al}_{\mathrm{S} . \mathrm{G} 700}\right.$, and $\left.\mathrm{Ni} / \mathrm{Al}_{\mathrm{S} . \mathrm{G} 800}\right)$ enhanced the incorporation of alumina cation into the $\mathrm{NiO}$ lattice.

\subsection{Metal-Support Interaction}

The TPR profiles of the Ni/Al S.G. catalysts are shown in Figure 3 to study the metal-support interaction. Two zones of reduction peaks are presented. The first zone was in the range of $200{ }^{\circ} \mathrm{C}$ to $370{ }^{\circ} \mathrm{C}$, which was observed in the $\mathrm{Ni} / \mathrm{Al}_{\mathrm{S} . \mathrm{G} 600}, \mathrm{Ni} / \mathrm{Al}_{\mathrm{S} . \mathrm{G} 700}$, and $\mathrm{Ni} / \mathrm{Al}_{\mathrm{S} . \mathrm{G} 1000}$ samples. These reduction peaks correspond to the reduction of the $\mathrm{NiO}$ species which has minimal or no interaction with the 
$\mathrm{Al}_{2} \mathrm{O}_{3}$ supports $[23,24]$. The other zone of reduction peaks was observed in all samples and located in the range of $450{ }^{\circ} \mathrm{C}$ to about $800{ }^{\circ} \mathrm{C}$, which may be attributed to the strong interaction of $\mathrm{NiO}$ and alumina support. As reported elsewhere, the formation of strongly interacting $\mathrm{NiO}-\mathrm{Al}_{2} \mathrm{O}_{3}$ phase was observed in the region between $550{ }^{\circ} \mathrm{C}$ and $750{ }^{\circ} \mathrm{C}[25,26]$. Notably, as the calcination temperature of the support increased $\left(\mathrm{Ni} / \mathrm{Al}_{\mathrm{S} . \mathrm{G} 600}, \mathrm{Ni} / \mathrm{Al}_{\mathrm{S} . \mathrm{G} 700}\right.$, and $\left.\mathrm{Ni} / \mathrm{Al}_{\mathrm{S} . \mathrm{G} 800}\right)$, the reduction bands shifted to higher temperature values until they reached a maximum value of $644{ }^{\circ} \mathrm{C}$ over the Ni/Al $\mathrm{l}_{\text {S.G800 }}$ catalyst. As a result, more $\mathrm{NiO}$ species were embedded more deeply in the $\mathrm{Al}_{2} \mathrm{O}_{3}$ lattice, thereby strengthening the interaction between the metal oxide and the carrier. This strong interaction promotes the distribution of the $\mathrm{NiO}$ species on the catalyst, which will further affect the steam reforming reaction. A further increase in the calcination temperature of the support beyond $800{ }^{\circ} \mathrm{C}\left(\mathrm{Ni} / \mathrm{Al}_{\mathrm{S} . \mathrm{G} 900}\right.$ and Ni/Al $\left.\mathrm{S}_{\mathrm{S} . \mathrm{G} 1000}\right)$ caused reduction bands to start to shift to lower temperature values. Consequently, more NiO species were located on the support surface, which indicates weaker interaction between the metal and the carrier as it caused nickel agglomeration and further affected the activity of the catalyst. Interestingly, bands belonging to $\mathrm{Ni}$ aluminate were not observed on all the examined catalysts, which coincides well with the XRD results.

Figure 3. Temperature-programmed reduction (TPR) profiles of nickel/sol gel alumina catalysts.

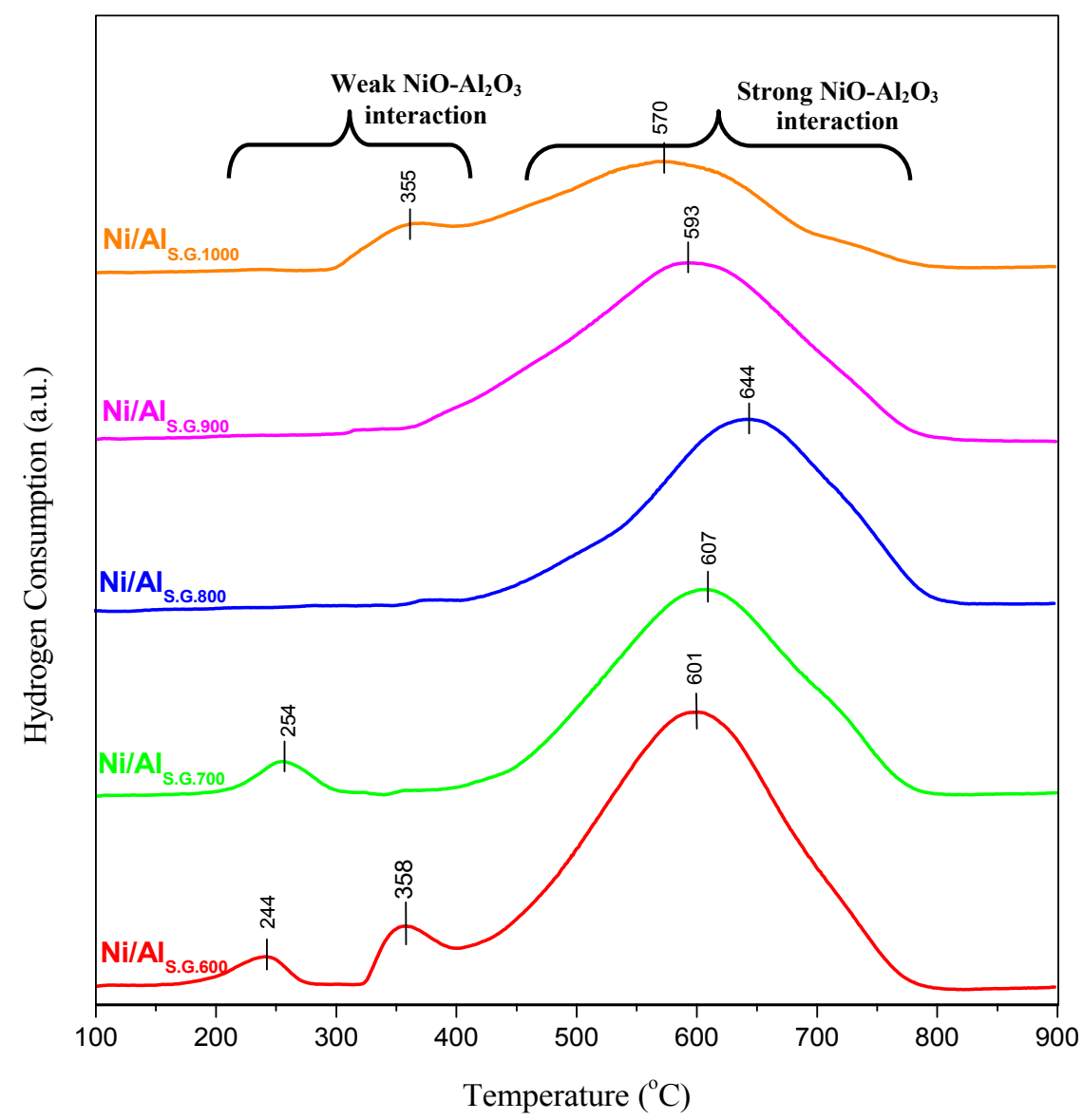

\subsection{Hydrogen Chemisorption Measurements}

The amount of $\mathrm{H}_{2}$ uptake, and dispersion, surface area, and mean particle size of nickel were determined through chemisorption measurements, as shown in Table 2. As a result of hydrogen 
chemisorption, the amount of hydrogen uptake over the $\mathrm{Ni} / \mathrm{Al}_{\mathrm{S} . \mathrm{G} 600}, \mathrm{Ni} / \mathrm{Al}_{\mathrm{S} . \mathrm{G} 700}$, and $\mathrm{Ni} / \mathrm{Al} 1_{\mathrm{S} . \mathrm{G} 800}$ catalysts increased as the calcination temperature increased. Furthermore, an increase in calcination temperature (Ni/Al $\left.1_{S . G 900}, \mathrm{Ni} / \mathrm{Al}_{\mathrm{S} . \mathrm{G} 1000}\right)$ led to a decrease in hydrogen uptake. The trend in the dispersion and surface area of nickel is proportional to the amount of hydrogen uptake. As a result, the dispersion and surface area of nickel increased in the following order: Ni/Al $\mathrm{S}_{\mathrm{S} . \mathrm{G} 600}<\mathrm{Ni} / \mathrm{Al}_{\mathrm{S} . \mathrm{G} 700}<\mathrm{Ni} / \mathrm{Al}_{\mathrm{S} . \mathrm{G} 1000}<$ $\mathrm{Ni} / \mathrm{Al}_{\mathrm{S} . \mathrm{G} 900}<\mathrm{Ni} / \mathrm{Al}_{\mathrm{S} . \mathrm{G} 800}$, whereas the mean particle size values of nickel decreased. These results are also supported by TPR experiments, as shown in Figure 3.

Table 2. Results for hydrogen chemisorptions measurements.

\begin{tabular}{|c|c|c|c|c|}
\hline Catalyst name & 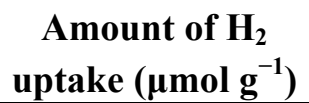 & $\begin{array}{c}\text { Nickel dispersion } \\
(\%) *\end{array}$ & $\begin{array}{l}\text { Nickel surface } \\
\text { area }\left(\mathbf{m}^{2} \mathbf{g}^{-1}\right) *\end{array}$ & $\begin{array}{l}\text { Mean particle } \\
\text { diameter (nm) }\end{array}$ \\
\hline $\mathrm{Ni} / \mathrm{Al}_{\text {S.G.600 }}$ & 45 & 4.40 & 1.75 & 22.9 \\
\hline $\mathrm{Ni} / \mathrm{Al}_{\text {S.G.700 }}$ & 254 & 24.8 & 9.90 & 4.1 \\
\hline $\mathrm{Ni} / \mathrm{Al}_{\text {S.G. } 800}$ & 566 & 55.4 & 22.1 & 1.8 \\
\hline $\mathrm{Ni} / \mathrm{Al}_{\text {S.G.900 }}$ & 489 & 47.8 & 19.1 & 2.1 \\
\hline $\mathrm{Ni} / \mathrm{Al}_{\text {S.G. } 1000}$ & 310 & 30.3 & 12.1 & 3.3 \\
\hline
\end{tabular}

\subsection{Steam Reforming of Ethanol over the Supported Ni Catalysts}

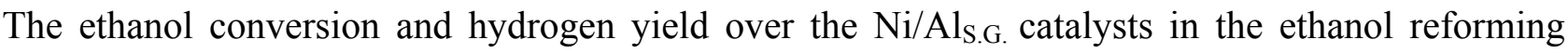
reaction as a function of the calcination temperature of $\mathrm{Al}_{\text {S.G. }}$ are shown in Figure 4 . Both ethanol conversion and hydrogen yield were significantly affected by the calcination temperature of the $\mathrm{Al}_{\text {S.G. }}$. supports. Catalyst deactivation was tested by evaluating the deposited carbon on the used samples to compare the performance of each catalyst after $8 \mathrm{~h}$ reaction. CHNS elemental analyses were performed to detect the quantity of carbon deposited on the used samples, as shown in Table 3. All samples contain only trace amounts of carbon. Therefore, catalyst deactivation by carbon deposition can be inferred to have an insignificant effect on catalytic activity after an $8 \mathrm{~h}$ run. The increase in both ethanol conversion and hydrogen yield was in the following order: $\mathrm{Ni} / \mathrm{Al}_{\mathrm{S} . \mathrm{G} 1000}<\mathrm{Ni} / \mathrm{Al}_{\mathrm{S} . \mathrm{G} 600}<$ $\mathrm{Ni} / \mathrm{Al}_{\mathrm{S} . \mathrm{G} 700}<\mathrm{Ni} / \mathrm{Al}_{\mathrm{S} . \mathrm{G} 900}<\mathrm{Ni} / \mathrm{Al}_{\mathrm{S} . \mathrm{G} 800}$. Among all the evaluated catalysts, the $\mathrm{Ni} / \mathrm{Al}_{\mathrm{S} . \mathrm{G} 800}$ catalyst exhibited the best catalytic performance. The high performance of the $\mathrm{Ni} / \mathrm{Al}_{\mathrm{S} . \mathrm{G} 800}$ catalyst may be due to its physical and chemical characteristics. Although the surface area and pore volume of the supports of the $\mathrm{Ni} / \mathrm{Al}_{\mathrm{S} . \mathrm{G} 600}$ and $\mathrm{Ni} / \mathrm{Al}_{\mathrm{S} . \mathrm{G} 700}$ catalysts were higher than those of the $\mathrm{Ni} / \mathrm{Al}_{\mathrm{S} . \mathrm{G} 800}$ catalyst (Table 1 ), the $\mathrm{Ni}$ species in the $\mathrm{Ni} / \mathrm{Al}_{\mathrm{S} . \mathrm{G} 800}$ catalyst interacted strongly with the alumina support (Figure 3 ). This strong metal-support interaction over the $\mathrm{Ni} / \mathrm{Al}_{\mathrm{S} . \mathrm{G} 800}$ catalyst not only improves the dispersion and surface area of nickel but also prevents metal agglomeration (Table 2). As a result, the number of active sites that can facilitate a reaction increased because of high metal dispersion. Consequently, this will enhance catalytic behaviour during the steam reforming reaction. Moreover, high dispersion of metal particles on the $\mathrm{Ni} / \mathrm{Al}_{\mathrm{S} . \mathrm{G} 800}$ catalyst could exhibit high resistance toward carbon formation. An attempt has been done by Seo et al. [19] to correlate the catalytic activity and selectivity of $\mathrm{Ni} / \mathrm{Al}_{\text {S.G. }}$ catalyst for steam reforming of natural gas and concluded that the support calcined at $900{ }^{\circ} \mathrm{C}$ is the most active system for hydrogen production, while our catalyst system shown highest selectivity and activity at calcined temperature of $800{ }^{\circ} \mathrm{C}$. 
Figure 4. Ethanol conversion and hydrogen yield over Ni/sol gel made alumina catalysts in the steam reforming of ethanol, plotted as a function of calcinations temperature of the support. The catalytic data were obtained after $8 \mathrm{~h}$ reaction.

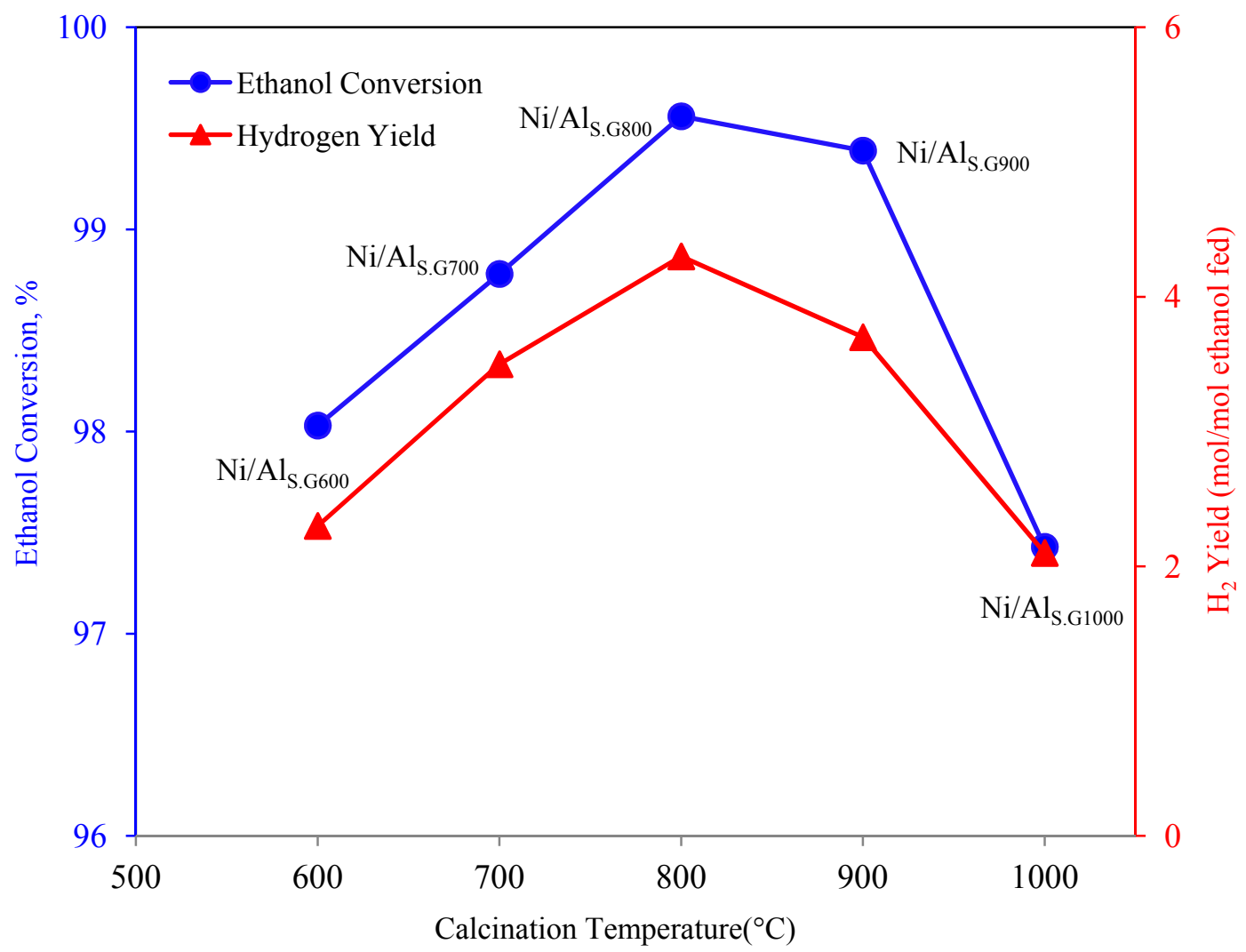

Table 3. Carbon deposited on the used catalysts after $8 \mathrm{~h}$ reaction.

\begin{tabular}{cc}
\hline Catalyst name & Amount of carbon deposition (wt \%) \\
\hline $\mathrm{Ni} / \mathrm{Al}_{\text {S.G. } 600}$ & 0.26 \\
$\mathrm{Ni} / \mathrm{Al}_{\text {S.G. } 700}$ & 0.20 \\
$\mathrm{Ni} / \mathrm{Al}_{\text {S.G. } 800}$ & 0.14 \\
$\mathrm{Ni} / \mathrm{Al}{ }_{\text {S.G. } 900}$ & 0.11 \\
$\mathrm{Ni} / \mathrm{Al}{ }_{\text {S.G. } 1000}$ & 0.68 \\
\hline
\end{tabular}

\section{Conclusions}

$\mathrm{Al}_{\text {S.G. }}$ supports were prepared and calcined at different temperatures. $\mathrm{Ni} / \mathrm{Al} \mathrm{l}_{\text {S.G. }}$ catalysts were synthesised by an impregnation method and then tested for $\mathrm{H}_{2}$ production via ethanol steam reforming. The influence of the calcination temperature of the $\mathrm{Al}_{\text {S.G. }}$ supports on the activity of the $\mathrm{Ni} / \mathrm{Al}_{\mathrm{S} \text {.G. }}$.

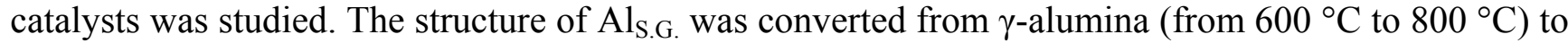
a mixed phase between $\gamma$ - and $\theta$-alumina (at $900{ }^{\circ} \mathrm{C}$ ) and then to $\theta$-alumina (at $1000{ }^{\circ} \mathrm{C}$ ). The increase in both ethanol conversion and hydrogen yield was in the following order: $\mathrm{Ni} / \mathrm{Al}_{\mathrm{S} . \mathrm{G} 800}>\mathrm{Ni} / \mathrm{Al}_{\mathrm{S} . \mathrm{G} 900}>$ $\mathrm{Ni} / \mathrm{Al}_{\mathrm{S} . \mathrm{G} 700}>\mathrm{Ni} / \mathrm{Al}_{\mathrm{S} . \mathrm{G} 600}>\mathrm{Ni} / \mathrm{Al}_{\text {S.G1000 }}$. Ni/Al S.G800 $_{\text {S. }}$ exhibited the best catalyst activity in terms of hydrogen yield and ethanol conversion. The strong metal-support interaction of the Ni/Al $1_{S . G 800}$ catalyst enhanced the dispersion and surface area of nickel while reducing mean particle size values, thereby resulting in high catalytic performance in terms of hydrogen yield. 


\section{Acknowledgments}

The authors gratefully thank the university authority for financial support provided for this work by the Universiti Kebangsaan Malaysia under the grants number of 03-01-02-SF0696 and ERGS/1/2011/TK/UKM/03/19.

\section{References}

1. Mariño, F.; Boveri, M.; Baronetti, G.; Laborde, M. Hydrogen production from steam reforming of bioethanol using $\mathrm{Cu} / \mathrm{N}_{\mathrm{i}} / \mathrm{K} / \gamma-\mathrm{Al}_{2} \mathrm{O}_{3}$ catalysts. Effect of Ni. Int. J. Hydrog. Energy 2001, 26, 665-668.

2. Llorca, J.; de la Piscina, P.R.; Dalmon, J.-A.; Sales, J.; Homs, N. CO-free hydrogen from steam-reforming of bioethanol over $\mathrm{ZnO}$-supported cobalt catalysts: Effect of the metallic precursor. Appl. Catal. B Environ. 2003, 43, 355-369.

3. Bshish, A.; Yaakob, Z.; Narayanan, B.; Ramakrishnan, R.; Ebshish, A. Steam-reforming of ethanol for hydrogen production. Chem. Pap. 2011, 65, 251-266.

4. Liu, Q.; Liu, Z.; Zhou, X.; Li, C.; Ding, J. Hydrogen production by steam reforming of ethanol over copper doped $\mathrm{Ni} / \mathrm{CeO}_{2}$ catalysts. J. Rare Earths 2011, 29, 872-877.

5. Pérez-Hernández, R.; Gutiérrez-Martínez, A.; Palacios, J.; Vega-Hernández, M.; Rodríguez-Lugo, V. Hydrogen production by oxidative steam reforming of methanol over $\mathrm{Ni} / \mathrm{CeO}_{2}-\mathrm{ZrO}_{2}$ catalysts. Int. J. Hydrog. Energy 2011, 36, 6601-6608.

6. Li, S.; Li, M.; Zhang, C.; Wang, S.; Ma, X.; Gong, J. Steam reforming of ethanol over Ni/ZrO catalysts: Effect of support on product distribution. Int. J. Hydrog. Energy 2012, 37, 2940-2949.

7. Li, Z.; Hu, X.; Zhang, L.; Liu, S.; Lu, G. Steam reforming of acetic acid over $\mathrm{Ni} / \mathrm{ZrO}_{2}$ catalysts: Effects of nickel loading and particle size on product distribution and coke formation. Appl. Catal. A Gen. 2012, 417-418, 281-289.

8. Rossetti, I.; Biffi, C.; Bianchi, C.L.; Nichele, V.; Signoretto, M.; Menegazzo, F.; Finocchio, E.; Ramis, G.; Di Michele, A. Ni/SiO 2 and $\mathrm{Ni} / \mathrm{ZrO}_{2}$ catalysts for the steam reforming of ethanol. Appl. Catal. B Environ. 2012, 117-118, 384-396.

9. Garbarino, G.; Lagazzo, A.; Riani, P.; Busca, G. Steam reforming of ethanol-phenol mixture on $\mathrm{Ni} / \mathrm{Al}_{2} \mathrm{O}_{3}$ : Effect of Ni loading and sulphur deactivation. Appl. Catal. B Environ. 2013, 129, 460-472.

10. Freni, S.; Cavallaro, S.; Mondello, N.; Spadaro, L.; Frusteri, F. Production of hydrogen for MC fuel cell by steam reforming of ethanol over $\mathrm{MgO}$ supported $\mathrm{Ni}$ and Co catalysts. Catal. Commun. 2003, 4, 259-268.

11. Fatsikostas, A.N.; Verykios, X.E. Reaction network of steam reforming of ethanol over Ni-based catalysts. J. Catal. 2004, 225, 439-452.

12. Frusteri, F.; Freni, S.; Spadaro, L.; Chiodo, V.; Bonura, G.; Donato, S.; Cavallaro, S. $\mathrm{H}_{2}$ production for $\mathrm{MC}$ fuel cell by steam reforming of ethanol over $\mathrm{MgO}$ supported $\mathrm{Pd}, \mathrm{Rh}, \mathrm{Ni}$ and Co catalysts. Catal. Commun. 2004, 5, 611-615.

13. Mariño, F.; Boveri, M.; Baronetti, G.; Laborde, M. Hydrogen production via catalytic gasification of ethanol. A mechanism proposal over copper-nickel catalysts. Int. J. Hydrog. Energy 2004, 29, $67-71$. 
14. Homs, N.; Llorca, J.; de la Piscina, P.R. Low-temperature steam-reforming of ethanol over $\mathrm{ZnO}$-supported $\mathrm{Ni}$ and $\mathrm{Cu}$ catalysts: The effect of nickel and copper addition to $\mathrm{ZnO}$-supported cobalt-based catalysts. Catal. Today 2006, 116, 361-366.

15. Sánchez-Sánchez, M.C.; Navarro, R.M.; Fierro, J.L.G. Ethanol steam reforming over $\mathrm{Ni} / \mathrm{M}_{x} \mathrm{O}_{y}-\mathrm{Al}_{2} \mathrm{O}_{3}(\mathrm{M}=\mathrm{Ce}, \mathrm{La}, \mathrm{Zr}$ and $\mathrm{Mg})$ catalysts: Influence of support on the hydrogen production. Int. J. Hydrog. Energy 2007, 32, 1462-1471.

16. Denis, A.; Grzegorczyk, W.; Gac, W.; Machocki, A. Steam reforming of ethanol over Ni/support catalysts for generation of hydrogen for fuel cell applications. Catal. Today 2008, 137, 453-459.

17. Seo, J.G.; Youn, M.H.; Cho, K.M.; Park, S.; Song, I.K. Hydrogen production by steam reforming of liquefied natural gas over a nickel catalyst supported on mesoporous alumina xerogel. J. Power Sources 2007, 173, 943-949.

18. Seo, J.G.; Youn, M.H.; Park, S.; Chung, J.S.; Song, I.K. Hydrogen production by steam reforming of liquefied natural gas (LNG) over $\mathrm{Ni} / \mathrm{Al}_{2} \mathrm{O}_{3}-\mathrm{ZrO}_{2}$ xerogel catalysts: Effect of calcination temperature of $\mathrm{Al}_{2} \mathrm{O}_{3}-\mathrm{ZrO}_{2}$ xerogel supports. Int. J. Hydrog. Energy 2009, 34, 3755-3763.

19. Seo, J.G.; Youn, M.H.; Park, S.; Song, I.K. Effect of calcination temperature of mesoporous alumina xerogel $(\mathrm{AX})$ supports on hydrogen production by steam reforming of liquefied natural gas (LNG) over Ni/AX catalysts. Int. J. Hydrog. Energy 2008, 33, 7427-7434.

20. Burtin, P.; Brunelle, J.P.; Pijolat, M.; Soustelle, M. Influence of surface area and additives on the thermal stability of transition alumina catalyst supports. I: Kinetic data. Appl. Catal. 1987, 34, 225-238.

21. Burtin, P.; Brunelle, J.P.; Pijolat, M.; Soustelle, M. Influence of surface area and additives on the thermal stability of transition alumina catalyst supports. II: Kinetic model and interpretation. Appl. Catal. 1987, 34, 239-254.

22. Chary, K.V.R.; Ramana Rao, P.V.; Venkat Rao, V. Catalytic functionalities of nickel supported on different polymorphs of alumina. Catal. Commun. 2008, 9, 886-893.

23. Rynkowski, J.M.; Paryjczak, T.; Lenik, M., On the nature of oxidic nickel phases in $\mathrm{NiO} / \gamma-\mathrm{Al}_{2} \mathrm{O}_{3}$ catalysts. Appl. Catal. A Gen. 1993, 106, 73-82.

24. Zieliński, J. Morphology of nickel/alumina catalysts. J. Catal. 1982, 76, 157-163.

25. Negrier, F.; Marceau, É.; Che, M.; de Caro, D. Role of ethylenediamine in the preparation of alumina-supported $\mathrm{Ni}$ catalysts from $\left[\mathrm{Ni}(\mathrm{en})_{2}\left(\mathrm{H}_{2} \mathrm{O}\right)_{2}\right]\left(\mathrm{NO}_{3}\right)_{2}$ : From solution properties to nickel particles. Comptes Rendus Chim. 2003, 6, 231-240.

26. Zhang, X.; Liu, J.; Jing, Y.; Xie, Y. Support effects on the catalytic behavior of $\mathrm{NiO} / \mathrm{Al}_{2} \mathrm{O}_{3}$ for oxidative dehydrogenation of ethane to ethylene. Appl. Catal. A Gen. 2003, 240, 143-150.

(C) 2013 by the authors; licensee MDPI, Basel, Switzerland. This article is an open access article distributed under the terms and conditions of the Creative Commons Attribution license (http://creativecommons.org/licenses/by/3.0/). 